\title{
Correction: Selection of reference genes for qRT-PCR examination of wild populations of Atlantic cod Gadus morhua
}

\author{
Pal A Olsvik, Liv Softeland and Kai K Lie
}

Following the publication of our article[1], an error in Table 2 was noted, the wrong accession number and primer sequences were stated for the EF1A assay.

The GenBank accession number was incorrectly stated as:

EX721840

Forward primer: CCCTGTGGAAGTGGCTGAAG

Reverse primer: CATCCAAGGGTCCGTATCTCTT

The correct GenBank accession number should be:

EX722124 Forward primer: CGGTATCCTCAAGCCCAACA Reverse primer: GTCAGAGACTCGTGGTG CATCT

We apologise for any inconvenience this may have caused.

Received: 24 October 2011 Accepted: 27 October 2011

Published: 27 October 2011

\section{Reference}

1. Olsvik PA, Softeland L, Lie KK: Selection of reference genes for qRT-PCR examination of wild populations of Atlantic cod Gadus morhua. BMC Research Notes 2008, 1:47.

* Correspondence: pal.olsvik@nifes.no

National Institute of Nutrition and Seafood Research, Nordnesboder 2, N5005 Bergen, Norway
Submit your next manuscript to BioMed Central and take full advantage of:

- Convenient online submission

- Thorough peer review

- No space constraints or color figure charges

- Immediate publication on acceptance

- Inclusion in PubMed, CAS, Scopus and Google Scholar

- Research which is freely available for redistribution
() Biomed Central 